How to Cite

Nurartha, I. N. P., Gorda, A. O. S., \& Anggreswari, N. P. Y. (2019). Hospital strategy in Gianyar regency facing the era of national health insurance. International Journal of Business, Economics \& Management, 3(1), 30-40.

https://doi.org/10.31295/ijbem.v3n1.110

\title{
Hospital Strategy in Gianyar Regency Facing the Era of National Health Insurance
}

\author{
I Nyoman Putra Nurartha \\ Undiknas Graduate School, Denpasar, Indonesia \\ Corresponding author email: dokputra78@gmail.com \\ A.A.N. Oka Suryadinatha Gorda \\ Universitas Pendidikan Nasional, Denpasar, Indonesia \\ Email: okagorda@gmail.com \\ Ni Putu Yunita Anggreswari \\ Universitas Pendidikan Nasional, Denpasar, Indonesia \\ Email: tata.anggreswari@undiknas.ac.id
}

\begin{abstract}
Premagana Gianyar Hospital as a private hospital has participated in the JKN program since the end of 2015. In its participation, Premagana Gianyar Hospital has experienced several problems due to the existing JKN system. Problems experienced are due to the fact that the number of costs incurred by the hospital is greater than the costs that come out, outpatient patients still need to be supported which certainly makes the costs incurred higher than the cost of the claim, and the latest on the BPJS Health online referral system is very detrimental, because, since the enactment of the online referral system, outpatient visits to the Premagana Gianyar Hospital polyclinic began to decline. A mature strategy is needed to face the era of BPJS Health in the future amid various issues and changes that occur. This study aims to determine the strengths, weaknesses, opportunities, and threats of Premagana Gianyar Hospital is facing the era of national health insurance and to find out the Business Strategy of Premagana Gianyar Hospital in Gianyar Regency in the face of the era of National Health Insurance. This study used descriptive qualitative method. The results of this study of the qualitative SWOT analysis of Premagana Gianyar Hospital conducted by researchers indicate that Premagana Gianyar Hospital, in accordance with the StrengthOpportunity Matrix, it shall have a profit stability strategy. Premagana Gianyar Hospital must maximize the opportunities that are still open through the advantages that they have. For the Weakness-Opportunity Matrix, Premagana Gianyar Hospital must change the strategy through the utilization of existing opportunities by overcoming the weaknesses of Premagana Gianyar Hospital. In the Strength Threat Matrix, suggesting a diversification strategy, Premagana Gianyar Hospital must use the strength to overcome existing threats. For the Weakness Threats Matrix, the strategies used by Premagana Gianyar Hospital should be sustained, by minimizing the weaknesses they have to avoid threats. Through the Qualitative SWOT analysis, Premagana Gianyar Hospital is able to compete with other private hospitals which see that the superiority of Premagana Gianyar Hospital is still dominant compared to the existing weaknesses. The use of opportunities must be smart through the advantages possessed without forgetting the existing weaknesses and threats in the JKN era.
\end{abstract}

Keywords---business strategy, SWOT analysis.

\section{Introduction}

In 2015, WHO in its meeting in Geneva announced that in 2030 the world community would be covered by the health insurance of each country. In Indonesia before 2014, many health systems were operating such as Askes, Jamkesmas, Asabri, and others. In the Province of Bali before the Indonesian government rolled out the National

ISSN 2632-9476

Received May 18, 2019/Accepted August 30, 2019/Published October 14, 2019 
Health Insurance (JKN) program on January 1, 2014, since 2010 it had already provided health insurance to its citizens through the Bali Mandara Health Insurance program (JKBM). As of July 31, 2018, the BPJS Health program has collaborated with 22,367 first-level health facilities. From that number, as many as 20,906 FKTP have connected their data communication network and can implement an online referral system. Lestari \& Budhi (2015), states that an institution is a system of social entities or organizations that make efforts to achieve certain goals. The word institutional has a core study of behavior with inherent values, norms, and rules. Private hospitals are an integral part of the national health system, although in reality private hospitals are not required to be providers of the national health system the role of private hospitals needs to be taken into account.

Premagana Gianyar Hospital is a private hospital in the Batubulan area of Gianyar Regency, Bali. Premagana Gianyar Hospital was opened on November 24, 2007, and recently obtained an operating license as Type C in January 2017. Premagana Gianyar Hospital is located in Batubulan village, Gianyar Regency, it is a private hospital that was established in 2007, with its vision of Making an Independent and Professional Hospital in 2020. Premagana Gianyar Hospital is a private, type C hospital with a total capacity of 63 beds, with the support of 30 specialist doctors both part and full time. Premagana Gianyar Hospital as a type C private hospital has participated in the JKN program since the end of 2015. Since the integration of all health systems in Indonesia to become one in 2013 several unsavory issues hit BPJS including the fact that in 2018 BPJS was declared to be experiencing deficits, online reference that applies a zoning system in several places, the difference in real tariffs by the hospitals and those issued by the BPJS, the increase in class which may only be done by 1 level making it problematic and dilemmatic for hospitals working with BPJS. According to Widyastuti (2017), the main obstacle when private type D and C hospitals become part of the provider of the national health system is the INA-CBGs tariff is not in accordance with the unit cost of services incurred. This is caused by differences in rates in the class of the hospital itself and the calculation of INA-CBGs which are not based on unit cost of service but refer to disease diagnosis. At present, private hospitals, especially types D and C, are at a crossroads, where their market segment is BPJS (National Health Insurance) Participants, and on the other hand INA-CBGs rates are generally unprofitable for them. Going forward, a mature strategy is needed to face the BPJS Health era amid various issues and changes that occur.

Based on the above phenomenon, the authors are interested in conducting research on this matter. Based on the explanation from the background described above, several problems can be formulated, among others: 1) What are the strengths, weaknesses, opportunities, and threats of Premagana hospital is facing the era of national health insurance? and 2) What is the business strategy of the Premagana Hospital in Gianyar Regency in facing the era of the National Health Insurance?

\section{Literature Review}

a) Strategy

Strategies are a series of managerial actions to improve long-term company performance, according to Poppy Rufaidah (2012). Whereas Assauri (2016), states that strategy is a collection of commitments to integrated and coordinated actions to seek or process competencies and at the same time in order to gain an organization's competitive advantage.

b) SWOT Analysis

Opinion put forward by Assauri (2016), states that SWOT analysis is an integrated analysis framework between the internal and external environment of the company whose purpose is to get a brief, precise, fast overview of the company's strategic situation. This analysis is based on logic that it can maximize Strengths and Opportunities, while simultaneously minimizing Weaknesses and Threats.

c) Business Strategy

According to Assauri (2019), there are five approaches that can be used to face competition and business operations. The five generic strategies, namely:

1) Low-cost leadership strategy

2) Broad differentiation strategy

3) Low-cost focus strategy

4) Focus strategy differentiation

5) Low-cost integration and differentiation strategies. 
d) Theoretical Framework for

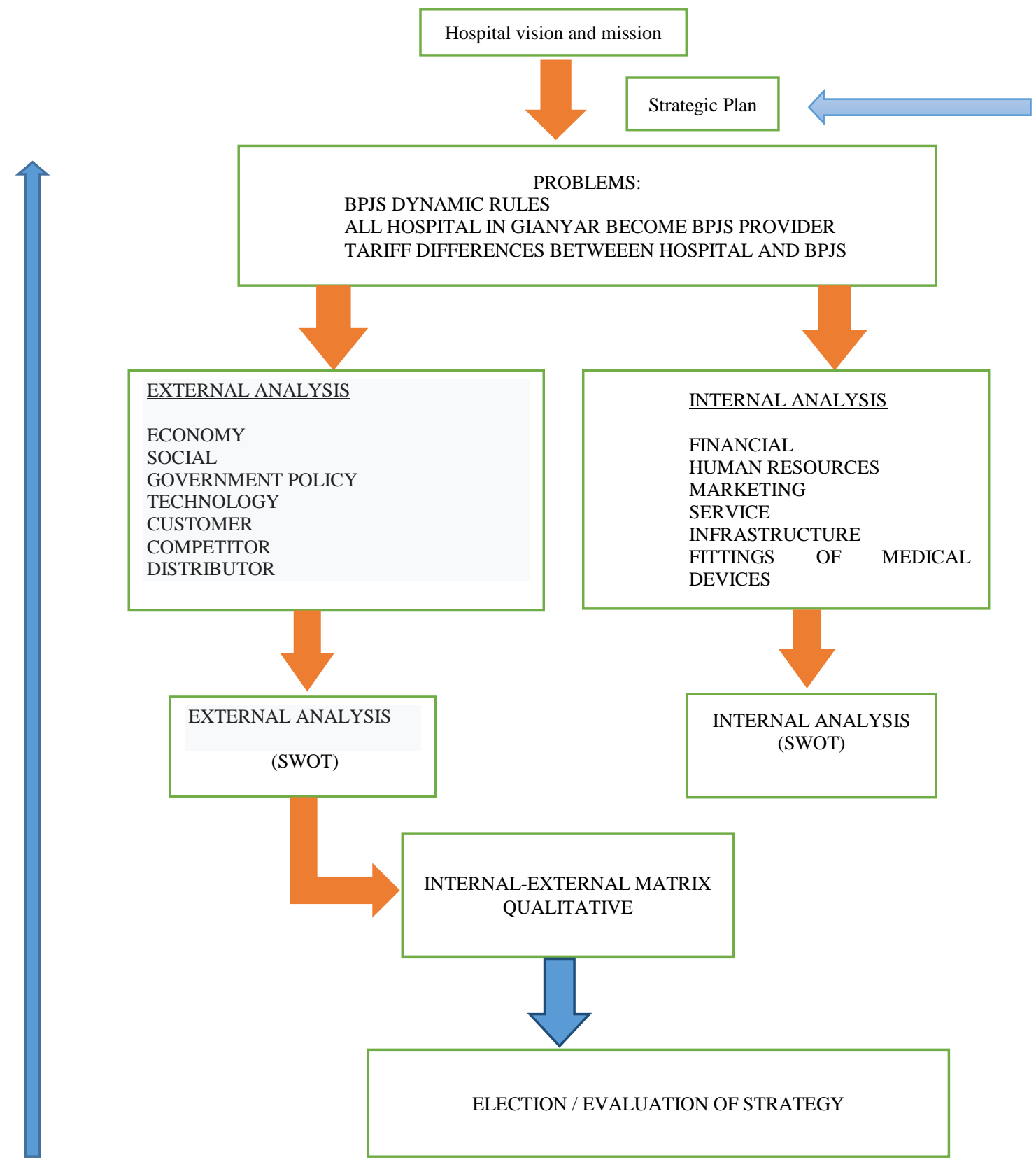

\section{Research Design}

This study uses descriptive qualitative research methods. The main objective of qualitative research is to understand social phenomena by focusing more on a complete picture of the phenomena that occur.

\section{Research Results}

1. SWOT Analysis of Premagana General Hospital In Facing the Era of National Health Insurance 
SWOT Matrix is used as a matching tool to assist in developing 4 types of strategies, namely SO strategy (strength/opportunity), WO strategy (weakness/opportunity), ST strategy (ST strengths/threats), and WT strategies (weaknesses/threats). The SWOT matrix is presented in the following form:

Table 1

SWOT Matrix of Premagana Gianyar Hospital in Facing the Era of National Health Insurance

\begin{tabular}{l} 
Strengths (S) \\
\hline a. Premagana Gianyar Hospital is dominated by \\
medical personnel (doctors), which is about 30 \\
specialist doctors and 8 remaining general \\
practitioners so that it impacts on maximum service \\
to patients.
\end{tabular}

b. Premagana Gianyar Hospital has complete medical facilities and adequate medicines so that it supports in providing optimal services.

c. Premagana Gianyar Hospital has a casemix team for optimizing the claim files for each BPJS patient whose goal is to increase turnover.

d. Premagana Gianyar Hospital has a quality control and costs control team to ensure financial efficiency that arises during maintenance.

e. Premagana Gianyar Hospital already has a clinical pathway in an effort to uniform the variety of services provided by doctors to each BPJS patient for efficiency in financing.

f. Premagana Gianyar Hospital has collaborated with official distributors who have affordable prices in terms of purchasing drugs and medical devices so as to reduce excess funding.

g. Premagana Gianyar Hospital has a brand in the community, especially in the district of Gianyar with superior midwifery and obstetric services.

h. Premagana Gianyar Hospital has quite a large number of outpatient services, namely 14 polyclinics.

i. Premagana Gianyar Hospital has passed the Prime level accreditation in 2017 valid until 2020.

j. j. Having superior services in the form of obstetric and gynecological services because of history and is supported by 11 obgyn specialist doctors.

k. Premagana Gianyar Hospital is dominated by medical personnel (doctors), which is about 30 specialist doctors and 8 remaining general practitioners so that it impacts on maximum service to patients.

1. Premagana Gianyar Hospital has complete medical facilities and adequate medicines so that it supports in providing optimal services.

m. Premagana Gianyar Hospital has a casemix team for optimizing the claim files for each BPJS patient whose goal is to increase turnover.

n. Premagana Gianyar Hospital has a quality control and costs control team to ensure financial efficiency that arises during maintenance.

o. Premagana Gianyar Hospital already has a clinical pathway in an effort to uniform the variety of a. Do not have additional working capital, making it difficult for Premagana Hospital operations.

b. Bailout funds are not enough to operate and invest.

c. In and out of employees which happens quite often will affect the performance of the hospital service itself.

d. Premagana Hospital in Gianyar has not been able to maintain maximum hospital hygiene because there are still several corners of the room that are uncomfortable to look at.

e. Premagana Gianyar Hospital position regarding zoning referral from BPJS. Where is the position of Premagana Gianyar Hospital which is located at the southern end of the Gianyar Regency becomes an obstacle when the patient determines the choice of health facilities from the BPJS because the maximum applicable patient distance to the hospital is $15 \mathrm{~km}$ while Batubulan is bordered by the eastern end of Denpasar City.

f. The hospital information system has not been integrated in the units so that it becomes an obstacle for the response in services.

g. h. Do not have an online registration system, which will facilitate access to every patient's registration to Premagana Gianyar Hospital.

h. Do not have additional working capital, making it difficult for Premagana Hospital operations.

i. Bailout funds are not enough to operate and invest.

j. In and out of employees which happens quite often will affect the performance of the hospital service itself.

k. Premagana Hospital in Gianyar has not been able to maintain maximum hospital hygiene because there are still several corners of the room that are uncomfortable to look at.

1. Premagana Gianyar Hospital position regarding zoning referral from BPJS. Where is the position of Premagana Gianyar Hospital which is located at the southern end of the Gianyar Regency becomes an obstacle when the patient 
services provided by doctors to each BPJS patient for efficiency in financing.

p. Premagana Gianyar Hospital has collaborated with official distributors who have affordable prices in terms of purchasing drugs and medical devices so as to reduce excess funding.

q. Premagana Gianyar Hospital has a brand in the community, especially in the district of Gianyar with superior midwifery and obstetric services.

r. Premagana Gianyar Hospital has quite a large number of outpatient services, namely 14 polyclinics.

s. Premagana Gianyar Hospital has passed the Prime level accreditation in 2017 valid until 2020.

t. j. Having superior services in the form of obstetric and gynecological services because of history and is supported by 11 obgyn specialist doctors. determines the choice of health facilities from the BPJS because the maximum applicable patient distance to the hospital is $15 \mathrm{~km}$ while Batubulan is bordered by the eastern end of Denpasar City.

m. The hospital information system has not been integrated in the units so that it becomes an obstacle for the response in services.

n. h. Do not have an online registration system, which will facilitate access to every patient's registration to Premagana Gianyar Hospital.

\section{Opportunity $(\mathrm{O})$}

a. Optimizing the Casemix team to get a turnover of claims submitted to BPJS every month.

b. Creating Executive Poly to reach other market segments.

c. Building intensive collaboration with clinics and health centers closest to the zoning area of the BPJS.

d. Maximizing BPJS services by such a large number of medical specialists such as midwifery and obstetrics building cooperation with midwives in their respective practices so that patients owned by midwives who will give birth are referred to the Premagana Gianyar Hospital

f. In the digitalization era, it is better to hope that all segments in the Premagana Gianyar Hospital play a role as hospital marketing to be able to increase the volume of patients and hospital goals.

g. Building a level 1 health facility clinic to get every BPJS patient earlier because of the enactment of the zoning system of BPJS.

\section{Threat (T)}

a. Besides Premagana Hospital in Gianyar, in the Regency of Gianyar also stands a Private Hospital which also operates near Premagana Gianyar Hospital.

b. There is no investment or additional capital from the commissioner or owner to the Premagana Gianyar Hospital for hospital operations so that they are able to sustain the hospital operations because BPJS payments are often delayed.

d. Regulations from the government which is always changing cause they are unable to fulfill the regulations optimally

e. Claims from BPJS that are often delayed up to 3-4 months result in not being able to provide maximum service to patients

Source: Data processed by researchers, 2019

\section{Hospital Strategy}

The SWOT analysis conducted by the author is a Qualitative SWOT analysis relating to the strategy of the Hospital in dealing with the National Health Insurance specifically. While the SWOT analysis carried out by Premagana Hospital is a general analysis in 2014, it is not a special analysis to deal with the era of national health insurance so the results can be different due to differences in the main system in making the analysis. As for the 2014-2019 Premagana Strategic Plan, the hospital is placed in quadrant I, which means the hospital is in an active or offensive position so that it can maximize its maximum strength to develop rapidly. By way of strengthening health services, opening a private wing of Relationship Marketing and Networking Alliance, to minimize the threat carried out the Survival Strategy through Internal Consolidation, 3rd party KSO and Quality Control of Cost Control. 


\section{Discussion}

\section{Premagana Hospital SWOT Analysis in Facing the National Health Insurance Era}

From the qualitative SWOT matrix above, it can be seen that the strength factor is greater than the weakness factor owned by Gianyar Premagana Hospital and the opportunity factor is also greater when compared to the threat factor.

\section{Internal Environment of the Premagana Gianyar Hospital}

Internal environment in the organization, namely strengths and weaknesses are situations and conditions within an organization that influence and interrelate one another in accordance with the organization's vision and mission to achieve service goals, human resources quality, promotion, cost/finance, and organization.

\section{a) Medical personnel resources}

According to the Regulation of the Minister of Health of the Republic of Indonesia Number 10 year 2018 concerning Supervision in the field of health, it defines that resources in the health sector are personnel, medical supplies, pharmaceutical preparations, and medical devices as well as health facilities, as well as technology used to carry out health efforts carried out by the Government, regional government and/or the private sector. Human resources owned by Premagana Gianyar Hospital are good enough, but the number of staff is still very adequate with the number of specialist doctors as many as 30 people and 8 general practitioners. The strength value possessed by the Premagana Gianyar Hospital, namely the number of obstetric and obstetrician specialists is an attraction for patients to choose the hospital in conducting the examination and the patient does not have to look for a hospital far from where the patient lives and even beyond the district.

\section{b) Quality Control and Cost Control Team}

The cost or service charge determination in Premagana Gianyar Hospital still has differences with the regulations determined by the BPJS. Thus, a quality control and cost control team is needed, referring to the Health Social Security Organizing Agency Regulation No. 8 of 2016 concerning the implementation of quality control and cost control, it stipulates that the development of quality control systems and payment systems for health services aims to improve the effectiveness of the implementation of health insurance. In the Premagana Gianyar Hospital a quality control and cost control team has been formed since 2018, with the task of monitoring the progress of patients being treated from entry to the patient leaving Premagana Gianyar Hospital. This is certainly a strength for Premagana Gianyar Hospital, wherein the JKN era the funding must be taken into account in every treatment so there is no loss for the hospital.

\section{c) Accreditation}

Minister of Health Regulation (Permenkes) No. 71 of 2013 concerning Health Services on the National Health Insurance (JKN) as updated through Permenkes No.99 of 2015 states that "Accreditation is one of the requirements that must be met by hospitals that want to become BPJS Health partners to serve JKN-KIS participants". Premagana Gianyar Hospital has passed accreditation since 2017 and is valid until 2020. This is certainly a strength because the health market in Indonesia is dominated by $95 \%$ by BPJS, so hospitals that do not pass accreditation will not be able to collaborate with any BPJS each year. Certainly, it is a positive value for hospitals because $95 \%$ of the health market share in the district of Gianyar is BPJS, thus there will be financial certainty later.

\section{d) Capital Weakness}

The definition of venture capital according to the Big Indonesian Dictionary in the research of Nugraha (2011) is money used as a principal for trading, releasing the money, and so on; property (money, goods, etc.) that can be used to produce something that adds to wealth. Thus according to the researchers working capital is very importantly needed by a company in carrying out its business activities. Weak working capital in addition to the BPJS claim disbursement system to hospitals often experience that are often delayed up to 3-4 months, certainly are the biggest threat factors for Premagana Gianyar Hospital.

\section{External Environmental Analysis}

External environmental factors are complex and always changing. These changes can take place quickly or slowly, both planned and unplanned but surely occur. In order that the organization does not experience setbacks, the 
organization must adapt to the response to changes that occur outside the organization. Premagana Gianyar Hospital's external environmental analysis is seen from several elements including:

\section{a) Competition}

According to Kotler (2009), competition has the definition that there is a race between companies to achieve greater market share. One of the strategic competing objectives for a business unit in an industry is finding a position in the industry where the company can protect itself well against competitive pressures or can positively influence these pressures. From the results of this study actually Premagana Gianyar Hospital.is quite capable of competing with private hospitals around it, because it has excellent services, has complete facilities and infrastructure, has a sufficient number of outpatient services and specialist doctors so that the opportunity to reach more patients is maximum. Drugs and tools availability are also quite complete by buying at an official distributor.

\section{b) Government Policies}

With increasingly stringent regulations governing the delivery of health services, making health services in Indonesia more effective, efficient, quality and safe. The policy issued by the local government regarding the zoning referral system turned out to pose a threat to Premagana Gianyar Hospital. The prevailing zoning referral system where the first BPJS health facility is the health center which will refer the patient to a public hospital must be $15 \mathrm{~km}$ away. Of course, this will benefit public hospitals where the first-level health facility is $15 \mathrm{~km}$ away from their area. There will be a flood of referrals for those hospitals, while public hospitals that only have 1 local clinic within its 15 $\mathrm{km}$ range would only get a few referrals, such as the Premagana Gianyar Hospital. This potential threat will have a serious impact if it is not handled by the management of Premagana Gianyar Hospital.because the level of visits will decrease and have an impact on the hospital's turnover.

\section{c) BPJS first-level health facilities}

Based on the Minister of Health regulation number 71, 2013 which includes PPK 1 (first-level health service providers) are as follows:

1) Local Clinic

2) Clinics

3) Class D hospitals (Hospitals established in disadvantaged villages, border or archipelago)

4) Practicing Doctor or dentist.

With the enactment of the zoning referral system in Gianyar district, Premagana Gianyar Hospital does not yet have PPK 1 clinic to screen patients early.

\section{d) The Casemix System}

According to the Casemix National Team of the Ministry of Health (2013), The Casemix system is a health service financing system that deals with quality, equity and affordability, which are several things in the mechanism of payment of health service costs for patients on a mixed case basis. The Premagana Gianyar Hospital.casemix team was established in 2017 in charge of handling patient examination files which will later be submitted as claims to BPJS. Optimization of every claim file made by the casemix team will increase the turnover obtained by the hospital, the hospital should always conduct training to the coders in the casemix team so that it is better in optimizing the files that will be submitted to BPJS.

\section{Strategic Plan of Premagana Gianyar Hospital.In Facing the National Health Insurance Era}

Based on the results of internal and external matrix analysis, a strategic plan that should be carried out by Premagana Gianyar Hospital.to be able to compete and improve quality in order to be able to achieve hospital goals optimally is the profit stability strategy. According to Nurhidayah (2018), the strategy is to maintain profits from hospitals by optimizing superior resources and superior services, along with efficiency that has been implemented such as forming quality control and cost control teams and implementing more diverse clinical pathways, while preparing further strategies.

Creating a first-level outpatient clinic in order to reach BPJS patients earlier in relation to referral zoning from BPJS 
The emergence of zoning regulations in referral will certainly not be balanced the number of patient referrals to the hospital. Strategic hospitals (many first-level health facilities in the region) will benefit greatly, and inversely with hospitals that are far from first-level health facilities will get the least referral. Regarding these rules, Premagana Gianyar Hospital should establish a Private Clinic to be able to get BPJS patients early so that it will support the existence of Premagana Gianyar Hospital, considering that 95\% of the current health market is controlled by BPJS.

\section{Make More Diverse Clinical Pathway.}

Based on the Minister of Health Regulation No. 1438 / MENKES / PER / IX / 2010 concerning Medical Services Standards, doctors and dentists in carrying out medical practices including in hospitals must be in accordance with standards. These standards include National Guidelines for Medical Services (PNPK) and SPM (Medical Service Standards). According to Firmanda (2006) \& Agbaeze et al., (2017), the definition of clinical pathway is an integrated service planning concept that summarizes each step that is given to patients based on medical services standard and evidence-based nursing care with measurable results and within a certain period of time while in hospital.

According to Firmanda (2006), Clinical Pathway can be used to predict the length of days treated and the cost of health services needed to optimize hospital resource utilization.

In the current era of National Health Insurance, by increasing the clinical pathway it will make optimal efficiency where there are significant differences in costs owned by the hospital with the costs set by the BPJS.

\section{Create executive polyclinics to reach BPJS and General premium markets.}

According to Regulation of the Minister of Health number 11 of 2016 concerning the implementation of executive outpatient arrangements in hospitals is the provision of non-regular outpatient health services in hospitals that are organized through specialist doctor-subspecialist services in one integrated room facility specifically without staying at the hospital with facilities and infrastructure above standard. Reaching the market segment in the premium class BPJS and the general public can be done through executive services, so that in the future not only the regular BPJS market can be served, but there are still people who are interested in wanting fast and convenient services.

\section{Improve casemix team performance to optimize BPJS claims every month.}

Some of the advantages of applying the Casemix Team to Health Services are:

a) Encouraging quality improvement

b) Encouraging patient-oriented services

c) Encouraging efficiency

d) Not giving rewards to providers who do overtreatment, under treatment or do adverse events.

e) Encouraging team service (coordination / collaboration between providers).

Premagana Gianyar Hospital has had a casemix team since 2017, currently the results have not been maximized, it is expected that with this team will have more value for Premagana Gianyar Hospital so that turnover optimization can be achieved.

\section{Establish cooperation with nearby clinics for optimizing referrals to Premagana Gianyar Hospital related to BPJS zoning rules}

Related to the BPJS referral zoning rules that apply in Gianyar regency, it is an obstacle of Premagana Gianyar Hospital in the current era of National Health Insurance. The unequal existence of first-level health facilities in Gianyar district which tends to be large in the northern part of the district of Gianyar clearly benefits hospitals that are within their reach. Premagana Gianyar Hospital itself is not included in the coverage of the region so it is necessary to optimize referrals with first-level health facilities that reach Premagana Gianyar Hospital by taking more pro-active visitation to those local clinics to campaign about the existing products and services that can be done at Premagana Gianyar Hospital.

\section{Maximizing existing superior services with innovative programs}

The existence of excellent services and competition that is so competitive for private hospitals in Gianyar Regency, it's time to expect the marketing team to carry out an innovation process in order to be able to achieve the 
targets set by the hospital management, according to with the opinions expressed by Tjiptono (2014), mix marketing is a set of tools that marketers can use to shape the characteristics of services offered to customers.

Utilization of information technology to all employees to be involved in marketing service products in Premagana Gianyar Hospital

For the advancement of the hospital, it is not enough to rely solely on the marketing team, all employees should be part of the marketing team by marketing several service products in the hospital through social media. Good information on specialist doctor's practice, special services such as pregnancy exercises, IVF programs can be marketed. If all employees are actively involved in marketing, it will certainly increase opportunities for Premagana Gianyar Hospital itself.

\section{Conclusion}

1. Qualitative SWOT analysis of Premagana Gianyar Hospital conducted by researchers shows that Premagana Gianyar Hospital has more strengths than the weaknesses. While with regard to the external factors, they have more opportunities than the threat factor.

2. Through Qualitative SWOT analysis of Premagana Gianyar Hospital, the strategy suggested by researchers is profit stability, through the following methods;

Maximizing the strength and opportunities that can be achieved by the Premagana Gianyar Hospital in facing the National Health Insurance are as follows:

a) Premagana Gianyar Hospital is dominated by medical specialists (doctors), which is 30 specialists doctors and 8 general practitioners so that it has an impact on maximum service to patients.

b) Premagana Gianyar Hospital has complete medical facilities and adequate medicines so that it supports in providing optimal services.

c) Premagana Gianyar Hospital has a casemix team to optimize the claims files for every BPJS patient whose goal is to increase turnover.

d) Premagana Gianyar Hospital already has a quality control and cost control team that aims at the efficiency of the costs incurred during maintenance.

e) Premagana Gianyar Hospital already has a clinical pathway in an effort to uniform the variety of services provided by doctors to each BPJS patient for efficiency in financing.

f) Premagana Gianyar Hospital has collaborated with official distributors who have affordable prices in terms of purchasing drugs and medical devices so as to reduce excess funding.

g) Premagana Gianyar Hospital has a brand in the community, especially in the district of Gianyar with superior midwifery and obstetric services. The brand owned is optimized even better through increased collaboration with midwives network or providing innovative services on midwifery and content.

h) Premagana Gianyar Hospital has quite a large number of outpatient services, namely 14 polyclinics. With so many polyclinics that are owned, they will be able to increase patient referrals from first-level health facilities because it will facilitate services if a patient has a disease that requires more treatment from one specialist doctor.

i) Premagana Gianyar Hospital has passed the Prime level accreditation in 2017 that is valid until 2020 so that it can work together with BPJS and can reach BPJS patients where the health market in Indonesia is currently dominated by BPJS.

j) It has superior services in the form of obstetric and gynecological services because of history and is supported by 11 obstetricians in obstetrics and gynecology fields.

Steps to minimize the weakness and threats for the Premagana Gianyar Hospital are as follows:

a) In addition to the Premagana Gianyar Hospital, in the Regency of Gianyar also stands a Private Hospital which also operates near Premagana Gianyar Hospital, this is another option for BPJS and level 1 health facilities to refer patients to the hospital.

b) There is no investment or additional capital from the commissioner or owner to the Premagana Gianyar Hospital for hospital operations so that they are able to sustain the hospital operations because BPJS payments are often delayed.

c) Regulations from the government that is always changing cause some regulations are not able to be fulfilled to 
the maximum because there will be problems with services.

d) Claims from BPJS which are often delayed for up to 3-4 months result in being unable to provide maximum service to patients due to operational fulfillments such as the need for procurement of medicines, consumables, and others.

\section{Suggestions}

Future research can analyze different cultural factors such as local wisdom in the study site to know whether it is a strength or a weakness factor.

\section{References}

Agbaeze, K. E., Monyei, E. F., \& Agu, O. A. (2017). Impact of talent management strategies on organizational performance in selected deposit money banks in Lagos State, Nigeria. International Research Journal of Management, IT and Social Sciences, 4(2), 135-151.

Assauri, S. (2016). Manajemen Operasi Produksi Pencapaian Sasaran Organisasi Berkesinambungan. Jakarta: PT Rajagafindo Persada.

Assauri, S. (2019). Rancang bangun sistem pendukung keputusan untuk pemilihan jurusan di perguruan tinggi dengan metode fuzzy electre i berbasis web (Doctoral dissertation, Universitas Airlangga).

Firmanda, D. (2006). Pedoman penyusunan clinical pathways dalam rangka implementasi sistem drgs casemix di rumah sakit.

Indonesian Minister of Health, 2015. RI Minister of Health Regulation No.99 of 2015 concerning Health Services on the National Health Insurance (JKN).

Kotler, P., \& Keller, K. L. (2009). Marketing Management, Edisi Tigabelas. Jilid II. Jakarta Erlangga.

Lestari, N. P. N. E., \& Budhi, M. K. S. (2015). Institutional strengthening and community empowerment model in the development of jatiluwih village as a community based ecotourism village.

Minister of Health Republic of Indonesia. (2010). Minister of Health Regulation No. 1438 of 2010. Regarding Medical Service Standards, doctors and dentists in carrying out medical practice.

Minister of Health RI, 2016. Minister of Health Regulation No. 64 of 2016. Concerning Service Tariff Standards in JKN.

National Health Insurance Administration Agency, 2016. Health Social Security Administration Agency Regulation Number 8 of 201. Regarding the implementation of quality control and cost control..

Nugraha, L. A. (2011). Pengaruh Modl Usaha, Tingkat Pendidikan, dan Sikap Kewirausahaan terhadap Pendapatan Usaha Pengusaha Industri Kerajinan Perak di Desa Sodo Kecamatan Paliyan Kabupaten Gunung Kidul. Universitas Negeri Yogyakarta.

Nurhidayah. (2018). Strategic Management Textbook. Yogyakarta: LP3M Muhammadiyah University.

RI Minister of Health, 2012. RI Minister of Health Regulation No. 12 of 2012. About Hospital Accreditation.

RI Minister of Health. (2013). Decree of the Director General of Health Efforts Development number HK.02.03 / I / 0253/2013. About the Establishment of the 2013 National Casemix Center Working Group.

RI Minister of Health. (2016). Minister of Health Regulation number 11 of 2016 concerning the implementation of executive outpatient care.

Rufaidah, P. (2012). Manajemen Strategik. Bandung: Penerbit Humaniora.

The Minister of Health of the Republic of Indonesia, 2018. Regulation of the Minister of Health of the Republic of Indonesia Number 10 of 2018. Concerning Supervision in the health sector.

Tjiptono, F. (2014). Pemasaran Jasa-Prinsip, Penerapan, dan Penelitian. Yogyakarta: Andi Offset.

Widiastuti, I. (2017). Services of the Health Social Security Administration Agency (BPJS) in West Java, Widya Scientific Journal, 4(1): 224-233. 


\section{Biography of Authors}

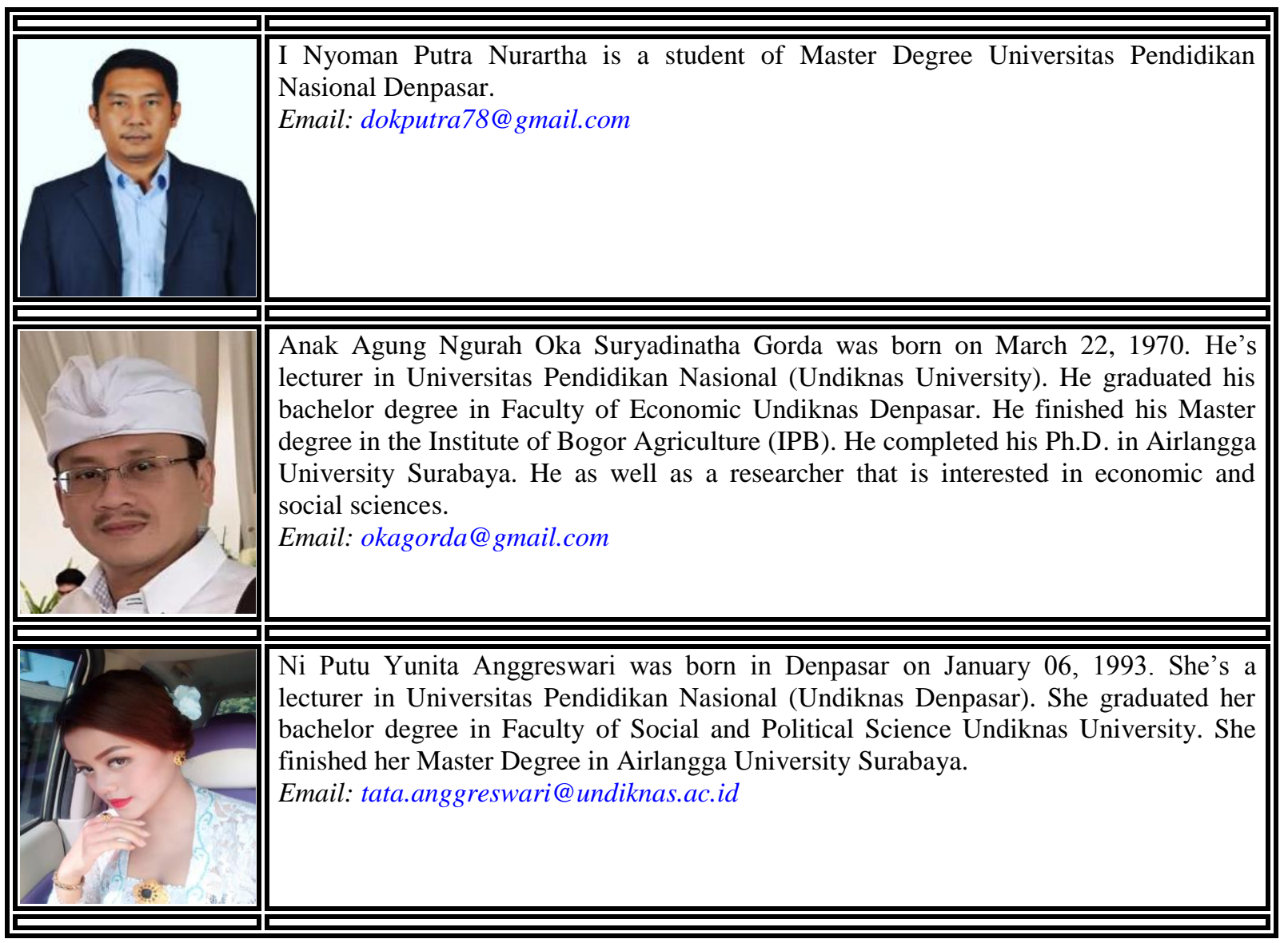

